\title{
Autumn migration of soaring birds at Bosporus: validating a new survey station design
}

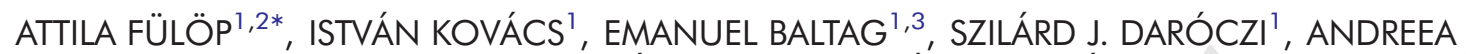
S. DEHELEAN ${ }^{\prime}$, LUCA A. DEHELEAN ${ }^{\prime}$, RÉKA B. KISS ${ }^{\top}$, ISTVÁN S. KOMÁROMI ', HANA LATKOVÁ ${ }^{\prime}$, TAMÁS MIHOLCSA ${ }^{1}$, ATTILA NAGY ${ }^{1}$, SZILÁRD Z. ÖLVEDI ${ }^{1}$, TAMÁS PAPP ${ }^{1}$, ATTILA K. SÁNDOR ${ }^{1}$, RÓBERT ZEITZ ${ }^{\top}$ AND MÁRTON A. KELEMEN ${ }^{\top}$

'Milvus Group' - Bird and Nature Protection Association, Crinului street 22, Târgu Mureş RO-540620, Romania;

${ }^{2}$ MTA-DE 'Lendület' Behavioural Ecology Research Group, Department of Evolutionary Zoology and Human

Biology, University of Debrecen, Egyetem tér 1, Debrecen H-4032, Hungary; ${ }^{3}$ Department of Zoology, Faculty of Biology, 'Al. I. Cuza' University, B-dul Carol I 20A, lași RO-700505, Romania

Capsule Using a new survey station network we report the highest number of migrating raptors and Black Storks ever recorded on Bosporus during the autumn migration period. Also, we show that migration occurs with similar intensities over the full length of the strait, but individual migration patterns differ for some species at a local scale.

Migration is an annual seasonal movement between regular breeding and wintering grounds, covering large geographical distances over continents, caused primarily by seasonal changes in food abundance (Newton 2008, 2010). Migration in birds is recognized as an energetically demanding process due to the long distances covered in flight, thus the flight strategy adopted can influence survival directly (Videler 2005). Migrating raptors and other large birds (e.g. storks, pelicans and cranes) minimize their energy expenditure and maximize their performance by employing a soaring-gliding flight style using thermals (Alerstam 1975, Pennycuick et al. 1979, Kerlinger 1989, Leshem \& Yom-Tov 1996, Spaar \& Bruderer 1996, 1997a, 1997b, Bildstein 2006). Thermals are columns of rising warm air that form mainly over the land, but not exclusively (Elkins 2004). Soaring birds exploit the uplifting force of the ascending warmer air mass, gaining height by circling up to high altitudes from where they can glide in their favoured migration direction (Leshem \& Yom-Tov 1996).

Over the course of their migration, soaring birds follow established air routes (flyways) where (1) the topography of the continent surface favours the
*Correspondence author. Email: attila.fulop@milvus.ro, fafeldolgozo@gmail.com development of thermals and (2) natural barriers (e.g. seas, deserts, ice fields or mountains) can be avoided or passed with minimum risk (Elkins 2004, Newton 2008). Typically, natural barriers are traversed using geographical bottlenecks such as narrow land bridges or sea crossings, where large concentrations of migrating soaring birds can be observed (Kerlinger 1989, Bildstein 2006, Newton 2008).

The Eurasian-East African flyway is one of the most important migration corridors globally, connecting northeastern Europe and western Siberia with southern Africa, by way of the Middle East (Zalles \& Bildstein 2000, Newton 2008). In the Middle East, soaring birds concentrate at three major geographical bottlenecks en route towards Africa: the Bosporus, Suez and Bab-elMandeb (Ferguson-Lees \& Christie 2001). The Bosporus Strait is the major bottleneck connecting Europe to Asia, hence several studies have been done to investigate the spring and autumn migration of raptors and other soaring birds in this region (Table 1).

Traditionally, the Çamlıca Hills (Büyük and Küçük Çamlıca) have been considered the most suitable survey stations for autumn migration counts (Steinfatt 1932, Nisbet \& Smout 1957, Ballance \& Lee 1961, Porter \& Willis 1968). The Büyük and Küçük Çamlıca, situated on the Asian side of the strait, are the highest points of Bosporus (268 and $227 \mathrm{~m}$, 
Table 1. A review of the studies published about autumn migration of soaring birds over the Bosporus.

\begin{tabular}{|c|c|c|c|c|c|c|}
\hline Year & Period & Locations & $\begin{array}{c}\text { Number of } \\
\text { days }\end{array}$ & Raptors & $\begin{array}{l}\text { Black } \\
\text { Storks }\end{array}$ & References \\
\hline 1931 & $\begin{array}{l}13 \text { September-4 } \\
\text { November }\end{array}$ & Büyük Çamlıca & 53 & 13199 & 516 & $\begin{array}{l}\text { Steinfatt (1932) (cited from Nisbet \& } \\
\text { Smout 1957) }\end{array}$ \\
\hline \multirow[t]{3}{*}{1956} & $\begin{array}{l}\text { 14-22 September and } 27 \\
\text { September-1 October } \\
15-16 \text { and } 20-22 \\
\text { September }\end{array}$ & $\begin{array}{l}\text { Büyük Çamlıca Küçük } \\
\text { Çamlıca } \\
\text { Kadiköy }\end{array}$ & & & & \\
\hline & 15 and 21 September & Çekmece & & & & \\
\hline & $\begin{array}{l}18 \text { and } 27-30 \text { September } \\
11-13 \text { September } \\
20 \text { September }\end{array}$ & $\begin{array}{l}\text { Büyükdere Rumehilisari } \\
\text { various parts of Istambul } \\
\text { Princess Islands }\end{array}$ & 16 & 8448 & 1376 & Nisbet \& Smout (1957) \\
\hline 1959 & 20 August-7 September & $\begin{array}{l}\text { Büyük Çamlıca Küçük } \\
\text { Çamlıca }\end{array}$ & 17 & 5396 & 110 & Balance \& Lee (1961) \\
\hline 1966 & 14 July-8 November & Küçük Çamlıca & 114 & 37139 & 6194 & Porter \& Willis (1968) \\
\hline 1969 & 25 August-13 October & Büyük Çamlıca & 51 & 61640 & 5700 & OST (cited from Arslangündoğdu (2011) \\
\hline 1971 & 13 August-4 October & Büyük Çamlıca & 53 & 75176 & 7208 & OST (cited from Arslangündoğdu (2011) \\
\hline 1972 & 5 August-6 October & $\begin{array}{l}\text { Büyük Çamlıca Küçük } \\
\text { Çamlıca }\end{array}$ & 63 & & 4300 & $\begin{array}{l}\text { Biilsma (1987) (cited from van den } \\
\text { Bossche \& Lens (1994)) }\end{array}$ \\
\hline 1973 & 8 September-3 October & Büyük Çamlıca & 26 & & 7400 & OST (Cramp \& Simmons 1980) \\
\hline 1975 & 9 August-2 October & Büyük Çamlıca & 50 & 26376 & 5246 & OST (cited from Arslangündoğdu (2011) \\
\hline 1980 & 31 August-4 October & $\begin{array}{l}\text { Büyük Çamlıca Küçük } \\
\text { Çamlıca }\end{array}$ & 35 & - & 5898 & $\begin{array}{l}\text { Biilsma (1987) (cited from van den } \\
\text { Bossche \& Lens (1994)) }\end{array}$ \\
\hline 1986 & 21-28 September & $\begin{array}{l}\text { Büyük Çamlıca Küçük } \\
\text { Çamlıca }\end{array}$ & 8 & - & 5049 & $\begin{array}{l}\text { Franckx and Verschueren (1989) (cited } \\
\text { from van den Bossche \& Lens (1994)) }\end{array}$ \\
\hline 1988 & 8 September-1 October & $\begin{array}{l}\text { Büyük Çamlıca Küçük } \\
\text { Çamlıca Sariyer }\end{array}$ & 24 & 58154 & 8781 & van den Bossche \& Lens (1994) \\
\hline 2007 & 1-30 September & Büyük Çamlıca & 30 & 24622 & 1679 & Arslangündoğdu (2011) \\
\hline 2008 & $\begin{array}{l}22 \text { September-10 } \\
\text { October }\end{array}$ & $\begin{array}{l}\text { Anadolu Kavăğ Koç Park } \\
\text { Büyük Çamlıca Kadiköy }\end{array}$ & 19 & 141844 & 16088 & Present study \\
\hline
\end{tabular}

respectively). Consequently, the majority of the studies concentrated on these hills, on the Southern part of the strait (Porter \& Beaman 1985). Since Bosporus is approximately $31 \mathrm{~km}$ long, significant numbers of birds may cross over other parts of it without being noticed. According to our knowledge, only one study has been published where a multi-station survey approach was used and counts were made systematically from three different points. van den Bossche \& Lens (1994) recorded the migration of soaring birds from Büyük and Küçük Çamlıca, and also from Sariyer, which is located on the European side of the Bosporus, $15 \mathrm{~km}$ north from the Çamlica Hills. Although the survey lasted approximately three weeks, van den Bossche \& Lens (1994) recorded the highest number of migrating Lesser Spotted Eagles Aquila pomarina over the Bosporus, with a total of 32228 individuals. Contrary to the suggestions made in previous studies (Nisbet \& Smout 1957, Porter \& Willis 1968), the majority of the Lesser Spotted Eagles passed the strait north of Çamlica Hills, at Sariyer. Although the observed migration pattern can be attributed to temporary weather conditions, it is possible that migration may occur throughout the total length of the Bosporus and not only at particular Southern points of it.

Even though the migration of soaring birds in the area of Çamlıca Hills is relatively well documented, migration in the other areas of the Bosporus remains poorly studied. In the present study we recorded the autumn migration of raptors and Black Storks Ciconia nigra over the Bosporus from four different survey stations simultaneously, validating the effectiveness of a new multi-station network. We provide data on the intensity and local pattern of migration of the soaring birds, and finally we suggest some future directions in the migration research over this geographical bottleneck.

The study was made from the Asian side of the Bosporus. Four stations were selected for observations in strategic places, situated mostly on high hills with good visibility, covering the total length of the strait (Fig. 1). The northernmost survey station was situated in the vicinity of Anadolu Kavağ 1 village, on the highest point of the hill, at the ruins of Yoros Castle 


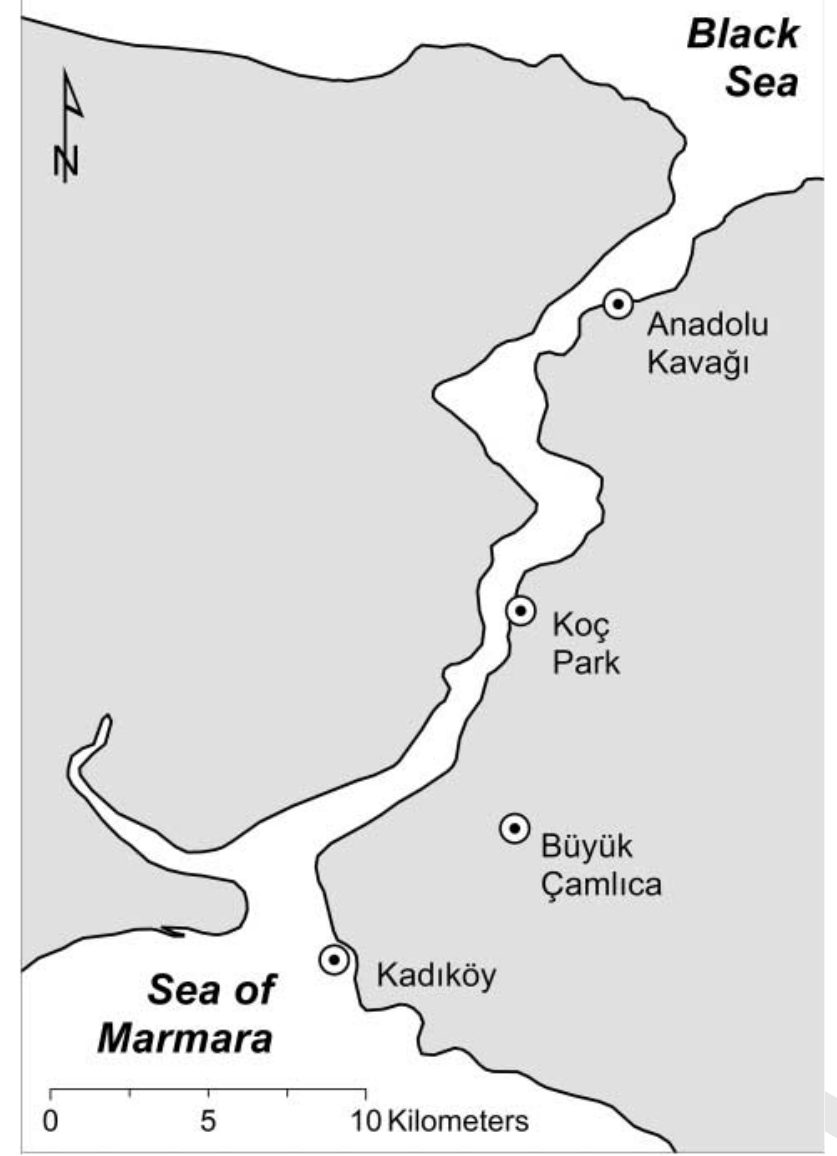

130

Figure 1. Map showing the exact locations of the survey stations on the Asian bank of the Bosporus.

(hereafter Anadolu Kavağı; N41.178922, E29.095375). Further south from Anadolu Kavağı station, the next survey station was located on the Otagtepe Hill, in the Tema Vehbi Koç Park (hereafter Koç Park; N41.09036, E29.07005) in the district of Beykoz. South from Koç Park, the third survey station was placed on the Büyük Çamlıca Hill (hereafter Büyük Çamlıca; N41.02810, E29.06836) in the district of Üsküdar. Lastly, the southernmost survey station was situated in the district of Kadiköy on the shore of the Sea of Marmara (hereafter Kadıköy; N40.99055, E29.01687). The distance between Anadolu Kavağ 1 and Koç Park survey stations was $10.06 \mathrm{~km}$, between Koç Park and Büyük Çamlıca was $6.92 \mathrm{~km}$ and finally between Büyük Çamlıca and Kadıköy was $6.01 \mathrm{~km}$.

The observations were made between 22 September and 10 October 2008. The survey period was chosen to cover primarily the migration peak of the Lesser Spotted Eagle, a species with global conservation concern. More than $95 \%$ of the breeding range of these species is in Europe (Bird Life International 2009) and the significant part from the global population migrates over Turkey at Bosporus (Cramp AQ1 \& Simmons 1980).

Counts were performed following the method described by Bird \& Bildstein (2007). Two to five observers were present at each survey station daily, between 9 and 18 hours (GMT + 3:00). Counts were carried out simultaneously at all stations and were suspended only in case of harsh weather conditions (e.g. heavy rain or thunderstorm), when migration stopped and also counting became impossible. The observers were equipped with binoculars (magnification $10 x$ ) and spotting scopes (magnification $20 \times, 30 \times$ and 20-60×). All observations were recorded on standard data sheets. Each bird was identified to species level if possible. In case of unidentified raptors, only the number of individuals was noted. When counting individuals one by one became impossible (e.g. rapidly migrating large flocks), individuals were counted in increments of 10 . The time of passage, distance to and direction related to the count point of individual birds or flocks were also noted.

Our final dataset presents the total number of migrating individuals counted at each survey station separately (including double counts) as well as the sum total number of migrants through Bosporus as recorded over the full study period (corrected for double counts). Double count correction was performed every day after observations, using the time of migration over the strait, distance and direction related to count points of the migrating birds (Agostini et al. 2007).

The total abundance of raptors recorded from our count points, as well as the individual abundances of the five most abundant raptor species and the Black Stork, were compared using Kruskal-Wallis test. In all cases when the categorical variable (count location) proved to be significant, post hoc comparisons were performed using Wilcoxon signed-rank test (package 'exactRankTests'; Hothorn \& Hornik 2013). Subsequent to the post hoc analyses, we have adjusted all $P$ values obtained using a Holm-correction, to exclude the type I error following multiple comparisons. We used a significance level of $P<0.05$. All statistical analyses were carried out in the $R$ statistical environment version 2.15.1 (R Core Team 2012).

We observed a total of 141844 individuals belonging to 25 raptor species and 16088 Black Storks. The most abundant raptor species were Common Buzzard Buteo buteo (52.2\%, 74055 individuals), Lesser Spotted Eagle (41.1\%, 58327 individuals), Short-toed Eagle Circaetus 
gallicus (2.9\%, 4242 individuals), Levant Sparrowhawk Accipiter brevipes (1.7\%, 2455 individuals) and Eurasian Sparrowhawk Accipiter nisus (1\%, 1450 individuals). The rest of the species $(n=20)$ were represented by less than $1 \%$ from the total of migrating raptors counted (Table 2).

No significant differences in the total abundance of raptors among the four survey stations were detected $\left(\chi^{2}=4.1, \mathrm{df}=3, P=0.25\right)$, nor in the abundance of Black Storks $\left(\chi^{2}=4.6, \mathrm{df}=3, P=0.19\right)$. Regarding the five most abundant raptor species, no significant differences were found among count points in the abundance of Common Buzzards $\left(\chi^{2}=2.0, \mathrm{df}=3, P=\right.$ 0.57), Levant Sparrowhawks $\left(\chi^{2}=1.1, \mathrm{df}=3, P=0.76\right)$ and Eurasian Sparrowhawks $\left(\chi^{2}=3.4, \mathrm{df}=3, P=0.32\right)$, but significant differences were found for Lesser Spotted Eagles $\left(\chi^{2}=17.4, \mathrm{df}=3, P<0.01\right)$ and Shorttoed Eagles $\left(\chi^{2}=23.7, \quad \mathrm{df}=3, \quad P<0.01\right)$. Post hoc analysis revealed significant differences in the abundance of Lesser Spotted Eagles between Anadolu Kavağı and Büyük Çamlıca $(W=274.5, \quad P<0.01)$, Anadolu Kavağı and Kadıköy $(W=282, P<0.01)$, Koç Park and Büyük Çamlıca $(W=276, P<0.01)$ and lastly Koç Park and Kadıköy $(W=288.5, P<0.01)$ survey stations. The abundance of Short-toed Eagles differed significantly between Anadolu Kavağı and Büyük Çamlıca $(W=277.5, P<0.01)$, Anadolu Kavağı and Kadıköy $(W=294.5, P<0.01)$, Koç Park and Büyük Çamlıca $(W=297.5, P<0.01)$ and Koç Park and Kadıköy $(W=306.5, \quad P<0.01)$. All significant differences between the survey stations obtained during the post hoc analysis remained significant after adjusting the $P$-values using the Holmcorrection.

In the present study, using a new survey station network, we report the highest number of migrating

Table 2. The complete list of species migrating at Bosporus recorded during the full study period.

\begin{tabular}{|c|c|c|c|c|c|}
\hline \multirow[b]{2}{*}{ Species name } & \multicolumn{5}{|c|}{ Survey station name } \\
\hline & Anadolu Kavağ & Koç Park & Büyük Çamlıca & Kadıköy & Total (corrected) \\
\hline \multicolumn{6}{|l|}{ Raptors } \\
\hline European Honey-buzzard Pernis apivorus & 122 & 14 & 27 & 11 & 174 \\
\hline Griffon Vulture Gyps fulvus & 30 & 28 & 2 & 1 & 55 \\
\hline Egyptian Vulture Neophron percnopterus & 4 & 0 & 0 & 0 & 4 \\
\hline Common Buzzard Buteo buteo & 6795 & 31765 & 12639 & 23133 & 74055 \\
\hline Long-legged Buzzard Buteo rufinus & 2 & 1 & 19 & 2 & 24 \\
\hline Booted Eagle Aquila pennata & 86 & 61 & 31 & 14 & 192 \\
\hline Eastern Imperial Eagle Aquila heliaca & 0 & 2 & 1 & 1 & 4 \\
\hline Steppe Eagle Aquila nipalensis & 0 & 2 & 0 & 1 & 3 \\
\hline Greater Spotted Eagle Aquila clanga & 2 & 0 & 2 & 2 & 6 \\
\hline Lesser Spotted Eagle Aquila pomarina & 17757 & 23803 & 11829 & 7454 & 58327 \\
\hline Western Marsh Harrier Circus aeruginosus & 6 & 6 & 32 & 5 & 49 \\
\hline Hen Harrier Circus cyaneus & 1 & 1 & 0 & 0 & 2 \\
\hline Montagu's Harrier Circus pygargus & 0 & 0 & 1 & 0 & 1 \\
\hline Pallid Harrier Circus macrourus & 2 & 1 & 1 & 0 & 4 \\
\hline Black Kite Milvus migrans & 1 & 8 & 24 & 9 & 42 \\
\hline Northern Goshawk Accipiter gentilis & 0 & 0 & 0 & 2 & 2 \\
\hline Eurasian Sparrowhawk Accipiter nisus & 274 & 438 & 371 & 374 & 1450 \\
\hline Levant Sparrowhawk Accipiter brevipes & 35 & 112 & 509 & 1799 & 2455 \\
\hline Short-toed Eagle Circaetus gallicus & 1928 & 1462 & 646 & 466 & 4242 \\
\hline White-tailed Eagle Haliaeetus albicilla & 1 & 0 & 0 & 0 & 1 \\
\hline Peregrine Falcon Falco peregrinus & 3 & 2 & 5 & 2 & 12 \\
\hline Common Kestrel Falco tinnunculus & 3 & 0 & 3 & 1 & 7 \\
\hline Red-footed Falcon Falco vespertinus & 27 & 18 & 42 & 18 & 105 \\
\hline Eurasian Hobby Falco subbuteo & 22 & 10 & 13 & 12 & 57 \\
\hline Osprey Pandion haliaetus & 1 & 0 & 0 & 0 & 1 \\
\hline Unidentified raptor Rapaces sp. & 104 & 420 & 37 & 14 & 570 \\
\hline Total & 27206 & 58154 & 26234 & 33321 & 141844 \\
\hline \multicolumn{6}{|l|}{ Non-raptors } \\
\hline Black Stork Ciconia nigra & 1717 & 6423 & 3479 & 5197 & 16088 \\
\hline
\end{tabular}

Individual abundances at the different survey stations present the total number of migrants observed including double counts. The overall abundances, which are corrected for double counts, are presented in the last column of the table. 
raptors and Black Storks ever recorded on the Bosporus during the autumn season. We show that migration occurs with similar intensities over the full length of the strait, and individual migration patterns differ between species at local scale. According to our knowledge, formerly the highest numbers of raptors were counted by the Ornithological Society of Turkey (OST), at 75176 individuals (as cited in Arslangündoğdu 2011). The highest number of Black Storks counted was 8781 individuals (van den 215 Bossche \& Lens 1994) (Table 1). Furthermore, we document the highest numbers of Common Buzzards, Lesser Spotted Eagles, Short-toed Eagles and Eurasian Sparrowhawks migrating through the Bosporus to date.

The two most abundant raptor species were the Common Buzzard and the Lesser Spotted Eagle, which constituted together $93.3 \%$ of the total of raptors observed. Our results are in accordance with previous studies, which have reported both species as being the most abundant ones migrating over the Bosporus in the similar period (Porter \& Willis 1968, van den Bossche \& Lens 1994). The high numbers of migrating Common Buzzards and Lesser Spotted Eagles recorded during our study can be attributed to the timing of our observation period, which overlapped with the peak migration of both species (Porter \& Willis 1968). The Short-toed Eagle, the Levant Sparrowhawk and the Eurasian Sparrowhawk were also abundant raptors, but much less so (in total $5.6 \%$ of the raptors observed) (Table 2), as has been reported in previous studies (Porter \& Willis 1968, van den Bossche \& Lens 1994). Although we have recorded a high numbers of individuals, compared to previous surveys, this can be attributed to us sampling the migration peak of the species only to a certain extent. Short-toed Eagles are the most abundant in a similar period (Porter \& Willis 1968), but Levant Sparrowhawks migrate earlier (van den Bossche \& Lens 1994, Arslangündoğdu 2011), and Eurasian Sparrowhawks migrate in low numbers during the whole autumn migration period, showing a peak in late October (Porter \& Willis 1968). The rest of the raptor species were represented in low numbers. These species either migrate in other periods, unrecorded in our study (e.g. European Honey-buzzard Pernis apivorus), or their migration is not so concentrated over geographical bottlenecks (e.g. Falco sp. and Circus sp.).

Previously the vast majority of the studies have been focused in the area of Çamlica Hills, due to the assumption that the majority of the soaring birds would pass the Bosporus by this route (Table 1). Contrary to these studies, but in agreement with van den Bossche \& Lens (1994), we have shown that migration occurs over the full length of the Bosporus, with similar intensity at different regions, because we have found no significant differences in the total abundance of raptors and Black Storks when comparing our survey stations. Furthermore, the highest abundance of migrants was recorded over the area of Koç Park and not over the Çamlica Hills. Among the five most abundant raptor species, we found that Lesser Spotted Eagles and Short-toed Eagles both preferred the Northern part of the strait to cross the Sea of Marmara. These results contradict Nisbet \& Smout (1957), but are similar to those described by van den Bossche \& Lens (1994), who observed large concentrations of migrating Lesser Spotted Eagles and also Short-toed Eagles at Sariyer, a point situated half way between our two northern survey stations, Anadolu Kavağı and Koç Park. The migration pattern of the species can be influenced by several factors: local weather and thermal conditions (Duerr et al. 2012), and species specific traits linked to body morphology: wing aspect ratio (wing $\operatorname{span}^{2} /$ wing area; Kerlinger 1985) and/or body size (Pennycuik 2008, Panuccio et al. 2013).

Future efforts should focus on laying the foundations of a long-term monitoring scheme over the Bosporus (as suggested by Leshem 1985). Systematic migration counts over similar geographical bottlenecks have proved to be a useful tool in estimating population trends of several raptor species (Bednarz et al. 1990, Agostini et al. 2007, Farmer et al. 2007). In the present study we provide the first evidence that such a scheme would be of outstanding value at the Bosporus. For example, we recorded 58327 individual Lesser Spotted Eagles. The estimated number of individuals in Europe, where $>95 \%$ of its breeding range lays, is between 42000 and 57000 individuals (Bird Life International 2013). Taking into consideration that we did not cover the full migration period of the species, and a small proportion of individuals migrate also at the Eastern coast of the Black Sea, at Batumi (Verhelst et al. 2011), we suggest, that the population size of the species may be underestimated. Furthermore, our study has limitations, hence additional surveys are needed to consider the following aspects: (1) the observation period should be extended to cover the full autumn migration season from mid-August to the end of October, (2) the effect of weather conditions on the timing and pattern of soaring bird migration should be 
determined precisely and (3) it should be tested whether more than four count points increase the amount and accuracy of the gathered data.

\section{ACKNOWLEDGEMENTS}

We are highly indebted to Dogan Simit and Ümit Yardim for their invaluable help in organizing the migration study camp. Tomáš Bělka, Romuald Mikusek, Petr Šaj, Zdeněk Vermouzek, Emilie Dauphas and Gregory Dhainaut kindly helped us during data collection. Travis Rosenberry and Meagan Kaiser of the Research Library of The Peregrine Fund, as well as Willem van den Bossche, generously provided us literature. Csongor I. Vágási and Zsolt Végvári kindly provided constructive criticism to a former version of the manuscript. Luke Dale-Harris improved our English.

\section{REFERENCES}

Agostini, N., Panuccio, M., Mellone, U., Lucia, G., Wilson, S. \& Ashton-Booth, J. 2007. Do migration counts reflect population trends? A case-study of the honey buzzard Pernis apivorus. Ardeola 54: 339-344.

Alerstam, T. 1975. Crane Grus grus migration over sea and land. Ibis 4: 489-495.

Arslangündoğdu, Z. 2011. Autumn-2007 migration of soaring birds across the Bosphorus Turkey. J. Fac. Forest. Istanbul Univ. 61: $37-42$.

Arslangündoğdu, Z., Dalyan, C., Bacak, E., Yardim, Ü., Gezcin, C. \& Bestkardes, V. 2011 . Spring migration of the White Stork Ciconia ciconia and the Black Stork Ciconia nigra over the Bosphorus. Zool. Middle East 53: 7-13.

Bagyura, J., Günes, B., Filotás, Z., Harangi, I., Haraszthy, L., Kalocsa, B., Boyla, K., Klinker, J., Tevely, R., Tamás, E.A. \& Viszló, L. 2006. Vonuló madarak számlálása a Boszporusznál 1993. Heliaca 74-79.

Ballance, D.K. \& Lee, S.L.B. 1961. Notes on autumn migration at the Bosphorus and in the Aegean. Ibis 103: 195-204.

Bednarz, J.C., Klem, Jr. D., Goodrich, L.J. \& Senner, S.E. 1990. Migration counts of raptors at Hawk Mountain as indicator of population trends 1934-1986. Auk 107: 96-109.

Bildstein, K. 2006. Migrating Raptors of the World: Their Ecology and Conservation. Cornell University Press, Ithaca, NY.

Bird, D.M. \& Bildstein, K.L. 2007. Raptor Research and Management Techniques. Hancock House Publishers, Surrey.

Bird Life International. 2013. Species factsheet: Aquila pomarina. Available from: http://www.birdlife.org [Accessed 2 August 2013].

van den Bossche, W. \& Lens, L. 1994. Soaring bird migration at the Bosphorus (Turkey): the need for a multi-station survey. Le Gerfaut 84: 51-62.

Cirik, O. \& Smith, L. 2006. Spring raptor migration at the Bosphorus Turkey in 2005. Abstracts of the XXIV International Ornithological Congress, Hamburg, Germany. J. Ornithol. 147(1): 149.

Cramp, S. \& Simmons, K.E.L. 1980. The Birds of the Western Palearctic Volume II. Oxford University Press, Oxford.

Duerr, A.E., Miller, T.A., Lanzone, M., Brandes, D., Cooper, J., O'Malley, K., Maisonneuve, C., Tremblay, J. \& Katzner, T. 2012. Testing an emerging paradigm in migration ecology shows surprising differences in efficiency between flight modes. PlosOne $\mathbf{7}$ doi: 10.1371/journal.pone. 0035548

Elkins, N. 2004. Weather and Bird Behaviour, 3rd edn. T \& AD Poyser, London.

Farmer, C.J., Hussell, D.J.T. \& Mizrahi, D. 2007. Detecting population trends in migratory birds of prey. Auk 124: 1047-1062.

Ferguson-Lees, J. \& Christie, D.A. 2001. Raptors of the World. Christopher Helm, London.

Hothorn, T. \& Hornik, K. 2013. exactRankTests: exact distributions for rank and permutation tests. $R$ package version $0.8-25$. Available from: http://CRAN.R-project.org/package=exactRankTests

Kerlinger, P. 1985. Water-crossing behavior of raptors during migration. Wilson Bull. 97: 109-113

Kerlinger, P. 1989. Flight Strategies of Migrating Hawks. Chicago University Press, Chicago.

Leshem, Y. 1985. Migration survey needs in the Middle East. In Chancellor, R. \& Meyburg, B.-U. (eds.) Birds of Prey Bulletin No. 2, 147-148. World Working Group of Birds of Prey and Owls, London.

Leshem, Y. \& Yom-Tov, Y. 1996. The use of thermals by soaring migrants. Ibis 138: 667-674.

Mauve, L. 1938. Der Zug der Grosvögel über den Bosporus. J. Ornithol. 86: $261-301$.

Meyer, S.K., Spaar, R. \& Bruderer, B. 2000. To cross the sea or to follow the coast? Flight directions and behaviour of migrating raptors approaching the Mediterranean Sea in autumn. Behaviour 137: 379-399.

Newton, I. 2008. The Migration Ecology of Birds. Academic Press, London.

Newton, I. 2010. Population Ecology of Raptors. T \& AD Poyser, London.

Nisbet, I.C.T. \& Smout, T.C. 1957. Autumn observations on the Bosphorus and Dardanelles. Ibis 99: 483-499.

Panuccio, M., Chiatante, G. \& Tarini, D. 2013. Two different migration strategies in response to an ecological barrier: Western Marsh Harriers and juvenile European Honey Buzzards crossing the central-eastern Mediterranean in autumn. J. Biol. Res. -Thessaloniki 19: 10-18

Pennycuick, C.J. 2008. Modelling the Flying Bird. Academic Press, London.

Pennycuick, C.J., Alerstam, T. \& Larsson, B. 1979. Soaring migration of the Common Crane Grus grus observed by radar and from an aircraft. Ornis Scand. 10: 241-251.

Porter, R. \& Willis, I. 1968. The autumn migration of soaring birds at the Bosphorus. Ibis 110: 520-536.

Porter, R.F. \& Beaman, M.A.S. 1985. A resume of raptor migration in Europe and the Middle East. In: Newton, I. (ed.) Conservation Studies on Raptors, (ICBP Technical Publication Series: No. 5) 237-240. Princeton University Press, Princeton.

R Core Team. 2012. R: A Language and Environment for Statistical Computing. R Foundation for Statistical Computing, Vienna. ISBN 3 900051-07-0. Available from http://www.R-project.org/

Richardson, W.J. 1978. Timing and the amount of bird migration in relation to weather: a review. Oikos 30: 224-272.

Spaar, R. \& Bruderer, B. 1996. Soaring migration of Steppe Eagles Aquila nipalensis in southern Israel: flight behaviour under various wind and thermal condition. J. Avian Biol. 27: 289-301.

Spaar, R. \& Bruderer, B. 1997a. Optimal flight behaviour of soaring migrants: a case study of migrating steppe buzzards Buteo buteo vulpinus. Behav. Ecol. 8: 288-297.

Spaar, R. \& Bruderer, B. 1997b. Migration by flapping or soaring: flight strategies of Marsh Montagu's and Pallid Harriers in Southern Israel. Condor 99: 458-469.

Steinfatt, O. 1932. Der Bosporus als Landbrücke für den Vogelzug zwischen Europa und Kleinasien. J. Ornithol. 80: 354-383. 
Üner, Ö., Boyla, K.A., Bacak, E., Birel, E., Çelikoba, I., Dalyan, C., Tabur, E. \& Yardim, Ü. 2010. Spring migration of soaring birds over the Bosphorus Turkey in 2006. Sandgrouse 32: 20-33.

Verhelst, B., Jansen, J. \& Vansteelant, W. 2011 . South West Georgia: an important bottleneck for raptor migration during autumn. Ardea 99: 137-146.
Videler, J.J. 2005. Avian Flight. Oxford University Press, Oxford.

Zalles, J.I. \& Bildstein, K.L. 2000. Raptor Watch: A Global Directory of Raptor Migration Site: A Global Directory of Raptor Migration Sites. Birdlife Conservation Series no. 9. BirdLife International, Cambridge. 